\title{
Keeping The Lights On With Coal Energy: A Financial Approach
}

Flory Anette Dieck-Assad, Ph.D., Tecnologico de Monterrey-Campus, Mexico

\begin{abstract}
Environmental, political, and economic events seem to conspire simultaneously towards the objective to erase coalfired power plants. The most important events are: the increase of environmental regulations, the surge of natural gas as a cleaner fuel, the operative costs, the aging and the efficiency issue of the coal-fired power plants. However, the decision of the U.S.A. Supreme Court, the $29^{\text {th }}$ of June 2015, suspended the regulation proposals presented by the U.S.A. Environmental Protection Agency concerning the mercury emissions of coal-fired power plants. This decision caused debate and controversy. The main objective of the sustainable approach for electricity generation is to find the blending of fuels that decrease contamination. However, the contradiction of different events in the world poses the challenge to evaluate if the XXI Century will see the end of the coal era. Could the technological breakthroughs like the Carbon Capture and Sequestration (CCS) and the development of other Clean Energy Technologies on Coal (CCT) stop this trend or, will the financial and environmental profitability of coal help it to remain in the energy mix?
\end{abstract}

Keywords: Coal; Power Plant; Clean Energy; Carbon Capture; Environmental Profitability

\section{INTRODUCTION}

"Managing power plant emissions from existing facilities is necessary to ensure our traditional manufacturing economy, our mining industry and our citizens can prosper in the face of increasingly more stringent federal regulations."

- Steve Beshear, Kentucky Governor

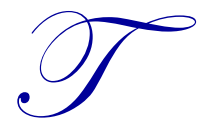

he Governor of Kentucky in the U.S.A., Steve Beshear, expressed these words in a written statement, at the funding announcement for the University of Kentucky Research Foundation (UKRF) from the federal government in 2011. UKRF research into cleaner-burning coal technology received a $\$ 19.4$ million dollar boost: \$14.5 million dollars from the U.S.A. Department of Energy (DOE) and \$4.9 million dollars from the state and industry partners. The objective of this grant was to support continued studies that seek to reduce costs and improve the carbon dioxide $\left(\mathrm{CO}_{2}\right)$ capturing from coal-fired power plants.

This grant was aimed to take technology they have developed in the laboratory to the E.W. Brown Generating Station (700 MW coal-fired power plant), located near Harrodsburg Kentucky, for field testing. UKRF seeks to find methods to reshape the coal-fired power plants on a large scale to make them less toxic. The DOE expects UKRF to develop technologies that can remove at least 90 percent of the $\mathrm{CO}_{2}$ emissions from these plants without increasing the cost of electricity over $35 \%$.

These efforts put the state of Kentucky in a leading position of developing methods to retrofit existing coal-fired power plants and making them less damaging to the climate (Bruggers, 2011). Kentucky is the third leading coal producing state in the U.S.A., its inhabitants get more than $90 \%$ of electricity from coal-burning power plants which generate $\mathrm{CO}_{2}$ emissions that rank them in seventh place of the total greenhouse gas (GHG) emissions in the U.S.A.

The specific dilemma of the state of Kentucky in the U.S.A. is how to keep the coal industry competitive after the fact that coal-burning power plants are among the leading sources of the GHG blamed for contributing to climate change. Finding ways to burn coal while managing $\mathrm{CO}_{2}$, considering the most recent federal global restrictions and regulations on pollutant emissions, may be a key for keeping Kentucky in the coal business, and saving its main source of income and employment. 
The events that are affecting the state of Kentucky, may also apply to other countries with abundant coal reserves, such as China, Colombia, and Mexico.

Some technological innovations propose to put a portion of a plant's flue gases in contact with a solvent, capable of absorbing $\mathrm{CO}_{2}$. When the $\mathrm{CO}_{2}$ and the solvent are heated together, the $\mathrm{CO}_{2}$ is released and captured, and the solvent is sent back to pick up more $\mathrm{CO}_{2}$. It is expected that the Carbon Capture, Sequestration and Storage technologies could be ready for widespread, affordable deployment by 2020 . Will that be too late for the climate change fight?

Nowadays, more and more utility companies are switching from coal to natural gas. However, they are still fighting to defend the use of coal in electricity generation. As an example, the Southern Company (one of the largest producers of electricity in the U.S.A.) - through its subsidiary Southern Generation Technologies - and KBR, Inc., have formed an alliance to market XXI century coal technology called Transport Integrated Gasification (TRIG), creating the next generation of carbon capture technologies (Southern Company, 2015).

According to Kolomitz (2012), officials from both companies believe that the innovative coal gasification process can provide coal-burning power plants with an efficient mean to generate electricity using an abundant, low-cost fuel low-rank coal -while significantly reducing $\mathrm{CO}_{2}$ emissions. The technology, which was developed by Southern Company and KBR, Inc. under the sponsorship of the U.S. Department of Energy, can support coal-based electricity generation with $\mathrm{CO}_{2}$ emissions comparable to those of natural gas plants.

Southern Company also partnered with China's Shenhua Group in the development of clean coal technologies. They expect to add more than 400,000 megawatts of coal-fired capacity by 2035 hoping to assist China with its carbon emission issue.

The dilemma of coal-burning power plants in the world raises the following question: Will it be possible to continue burning coal while managing $\mathrm{CO}_{2}$ emissions through clean coal technologies in due time to fight climate change?

The objective of this study is to understand the dilemmas of coal-fired electricity generation through a deeper comprehension of the process in which coal is used as fuel to generate electricity, to identify environmental alerts that these power plants may cause, and to present a brief comparison of electricity generation costs using different technologies in order to have a better view of the role that coal could play in the fuel mix of electricity generation in the XXI Century.

There are many available upgrades that can be applied to coal-fired power plants to make them more efficient, but these improvements will be in the hands of engineers who set up a plant (each can have different particular conditions). Therefore, technical aspects will not be discussed in this paper but the financial approach required for sustainable electricity generation.

\section{COAL-FIRED POWER PLANTS}

Coal has been one of the most used energy sources, especially in the XIX and first half of the XX Century. For some countries, coal is still one of the energy hopes for the XXI Century.

Coal is a mineral that can reach ideal controllable temperatures very quickly when heated, becoming an important source of energy for the world. The rate of reaction from the chemical point of view is very fast, and this may be one reason why coal is widely used for generating heat (Rincon, 2002).

In a thermal plant, there are different types of fuels that can feed the boiler where water is converted into steam for the generation of electricity. With different characteristics of temperature and pressure, the steam makes turbines connected to generators to produce electricity (Cengel \& Boles, 2012).

The fuels that feed the boiler to heat water and take advantage of the steam generated are usually: oil, natural gas or coal; if you use the high temperature water from inside the earth, it is called geothermal energy. There are other ways to generate electricity, known as renewable energies, such as those that move the generators with the wind (wind energy) or the pressure that water streams can generate in a dam (hydroelectric). 
This paper will analyze the use of coal as fuel for the boiler that produces steam at high pressure and temperature to generate electricity in the turbine and generator. This plant is called thermal, because it is fueled mainly by coal. This process consists of various steps taken for water control and efficiency within the plant itself (Ortuño, 1998). The main components of this plant are: the water pump, the boiler (where the water is heated to generate steam), turbines (where steam at high pressure and temperature will spin generators to produce electricity), and the condenser (where the steam is cooled and condensed for reuse in the process).

For the storage of coal, in the case of coal-fired power plants, mineral coal is stacked in special rooms which are connected to channels where the coal will be carried to the crusher before taking it to the boiler. The crushed coal is moved by conveyor belts to be sent to the boiler, where it can be mixed with water or other fossil fuels such as oil, under high pressure, to heat water and generate steam. The remaining coal ashes should also be stored to prevent environmental pollution; these ashes can also be used in civil engineering projects such as construction fills, replacement of cement in concrete or prefabricated elements (Martinez-Prado et al, 2014).

Often, coal and oil contain sulfur compounds which generate, after their combustion, sulfur dioxide that is released into the atmosphere; it returns to the earth's surface in the form of acid rain. The sulfur dioxide emissions in coal power plants can be reduced in three ways:

- Coal pretreatment

- Treatment during combustion

- Elimination of the sulfur dioxide from the flue gases

It has been found that pretreatment of coal can remove only 5 to $30 \%$ of sulfur. The combined remaining sulfur is part of the carbon structure and cannot be removed by physical processes such as washing it. The gas desulfurization processes are widely accepted in pulverized coal power plants, although investment and operating costs of an additional plant required to do so, highly increases the cost of electricity. Therefore, efforts have focused on processes in which sulfur is removed with the ash in the combustion system or in another reactor.

All fossil fuels release $\mathrm{CO}_{2}$ during combustion. $\mathrm{CO}_{2}$ is responsible for about $50 \%$ of the effects caused by the GHG emissions, including methane, nitrous oxide and chlorofluorocarbons, impacting the balance of gases in the atmosphere which give rise to an increase in temperature that cause the debated "global warming". It is also possible that small amounts of elements such as lead, cadmium and arsenic, could be released to the air during combustion.

Burning coal also releases mercury into the environment. Coal-fired power plants are the main source of mercury air emissions in the U.S.A. and represent about 40 percent of all mercury emissions into the country; for this reason, the decision of the US Supreme Court (June 29, 2015), which suspended the proposed regulation of the EPA (Environmental Protection Agency) on mercury emissions from coal-fired power plants was hotly debated.

The consequences of releasing mercury into the air is that, eventually, it settles into water and soil where water can flow. Once deposited there, the microorganisms can change it into methylmercury, a highly toxic compound that builds up in fish, shellfish and fish fed animals which in turn could be passed to humans in the food chain.

\section{TECHNOLOGICAL DEVELOPMENTS}

The company $\mathrm{CO}_{2}$ Solutions Inc. (2015), a leading technology developer for the Carbon Capture and Sequestration (CCS), announced on April 2015 that they have managed to reduce the process costs of making CCS commercially viable through their research in the EERC (Energy \& Environmental Research Center) using a new enzyme-based technology. The results showed that operating costs are significantly lower, getting results 10 years ahead of those expected by the DOE technology based on another enzyme (amine-based technology).

The DOE has invested more than $\$ 3.4$ billion dollars in five research projects looking for the best way to use coal as fuel. One such project is the pilot power plant in Kemper, Mississippi, U.S.A. which will begin operations in 2016 and will use 4,000 million tons of reserves of a type of soft coal called "lignite" found in the state of Mississippi. This power plant will have a $582 \mathrm{MW}$ capacity and will use TRIG TM technology (Transport Integrated Gasification: coal to gas technology). 
Will technological breakthroughs change the fate of coal-fired power plants in the future? The dilemma is to unfold the cheaper technologies for CCS, and/or an efficient method of converting coal to gas for use in electric power generation.

For the chemical characteristics of easy combustion of coal as well as the existence of large coal reserves in the world (it is cheap, abundant and secure), technological advances created to make it a nature-friendly energy source, don't stop. Without being exhaustive, a list of clean coal technologies have been found to date, which aim to transform coal into a sustainable fuel that could surprise the world in the XXI Century. These are:

1. Gasification technologies.

2. Synthetic gas.

3. Coal-to-liquids that converts synthetic gas into hydrocarbons.

4. Integrated Gasification Combined Cycle process.

5. Carbon Capture and Sequestration.

\section{PLUTARCO ELIAS CALLES COAL-FIRED PLANT}

The coal-fired plant Plutarco Elias Calles (Petacalco), located in La Union, in the state of Guerrero, Mexico, had an installed capacity to generate 2,100 MW in November 1993 through 6 generators; in February 2010 a seventh generator with an installed capacity of $678 \mathrm{MW}$ was added, achieving a total installed capacity to generate 2,778 MW of electricity. It has 15 electricity transmission lines in three states of Mexico (Estado de Mexico, Michoacan, and Guerrero): 4 of $400 \mathrm{KV}, 7$ of $230 \mathrm{KV}$ and 4 of $115 \mathrm{KV}$. For its capacity, it is considered one of the largest of its kind in Latin America. The plant consumes coal imported from Australia, with an estimated 5.47 million tons per year. It generates $7 \%$ of total electricity in Mexico. There are other coal plants installed in Mexico and known as Jose Lopez Portillo (1,200 MW) and Carbon II (1,400 MW): both are installed in the state of Coahuila.

According to environmentalists (Greenpeace, 2002), Petacalco generates 17.7 million tons of CO2 every year, becoming the most polluting power plant in Mexico.

In addition to $\mathrm{CO}_{2}$, Petacalco generates:

1. Ashes: impacting the mango, lemon, and grapefruit crops.

2. Sulfur Dioxide $\left(\mathrm{SO}_{2}\right)$, which causes acid rain harming fish and other aquatic life.

3. Nitrogen monoxide (NO), mercury, and other pollutants.

4. Hot water: the water used to cool the turbines come from the Balsas River and is thrown into the sea at high temperatures, causing the death of many marine species;

5. Lead waste, carbon, and uranium are also thrown into the sea.

\section{FINANCIAL ANALYSIS OF COAL-FIRED PLANTS}

The financial and economic analysis of the costs of electricity begins with the classification of two main concepts: the investment cost and the cost of generation.

The investment cost or installation cost is the capital invested in the construction of a power plant, with any type of fuel. This value is expressed in absolute value (U.S. \$) to consider the total amount invested in building a plant, or a specific value per unit of power generation capacity (U.S. $\$ / / \mathrm{KW}$ ).

The cost of generation is expressed in U.S.C/KWh, which indicates the actual cost of producing a unit of energy of electricity, including both fixed and variable costs, that is, it includes the equivalent levelized cost (used for the comparison of different methods of electricity generation), operation, fuels, and maintenance costs.

When speaking of equivalent levelized cost in U.S.C/KWh, it is the sum of the total investment cost converted into an equivalent variable cost in terms of U.S.C/KWh; this is achieved by turning it into an equivalent payment by period during the useful life of the respective power plant, proportional to the power generated in that period. This cost is an 
appropriate economic indicator for visualizing the minimum cost that should be covered in order to reach the financial point of equilibrium for the project.

The World Bank's ESMAP (Energy Sector Management Assistance Program) simulated the equivalent levelized cost by technology for 2025 in its 2007 published report. Table 1 presents the estimates for 2025 which are compared to those registered in 2005. It is identified that coal will continue to be a cheap fuel per generated KWh in 2025 .

Table 1. Simulation of Generation Costs by Type of Technology for $2025^{*}$

\begin{tabular}{l|c|c|c}
\hline Type of Technology & $\begin{array}{c}\text { Capacity } \\
\text { MW }\end{array}$ & $\begin{array}{c}\text { 2005 Generation Cost } \\
\text { U.S. C / KWh }\end{array}$ & $\begin{array}{c}\text { 2025 Generation Cost } \\
\text { U.S. C / KWh }\end{array}$ \\
\hline Hydroelectric & 100 & 5.4 & 5.2 \\
\hline Natural gas: combined cycle & 300 & 5.6 & 5.1 \\
\hline Coal: Steam turbine & 300 & 4.5 & 4.2 \\
\hline Eolic & 100 & 5.8 & 4.7 \\
\hline Solar (photovoltaic) & 5 & 41.6 & 32.7 \\
\hline Geothermal & 20 & 6.7 & 6.3 \\
\hline Diesel (Fuel oil) & 5 & 9.3 & 8.8 \\
\hline Biomass & 50 & 6.0 & 5.7 \\
\hline $\begin{array}{l}\text { *The generation cost includes the equivalent levelized cost and operation, fuel and maintenance costs. Source: The World Bank (2007); Boulanger, } \\
\text { et al (2009). }\end{array}$
\end{tabular}

Table 1 shows that the investment cost of a steam turbine fed with coal as a fuel presents the lowest cost; however, there are often other variables that influence the decision when identifying the best technology for generating electricity in a country. For example, it could be the geological conditions of the place where electricity needs to be generated; in a place where coal is abundant, that country could take advantage of steam turbines technology with coal as fuel (Girardin, 2011).

This would be for example the case of Colombia which has the largest coal reserves in the region of Latin America and the Caribbean. And for many countries where its priority is energy security, their decision doesn't necessarily have to match the best economic, profitable or ecological scenarios, which would pass to a secondary matter when the national priority is to ensure the supply of energy for its people.

Yepez-Garcia, et al (2010) calculated a simulation of the equivalent levelized cost in 2008 for different technologies, adding another important variable: the market price of an oil barrel. The results confirm again that coal will continue to be a cheap fuel (Table 2). It can be seen that regardless of a low or a high price of an oil barrel scenario, coal is still the most competitive fuel. Hydropower, although very cheap, has the problem of requiring a substantial initial investment when building the plant.

Table 2. Equivalent Levelized Cost U.S. C/KWh

\begin{tabular}{l|c|c|c}
\hline & Oil Barrel Price U.S.\$ & $\mathbf{1 0 0}$ & $\mathbf{1 5 0}$ \\
\hline Type of Technology & $\mathbf{5 0}$ & 6.4 & 7.8 \\
\hline Natural gas: combined cycle & 4.4 & 3.9 & 3.9 \\
\hline Hydroelectric & 3.9 & 4.9 & 5.2 \\
\hline Coal: Steam turbine & 4.1 & 7.7 & 7.7 \\
\hline Geothermal & 7.7 & 7.8 & 7.8 \\
\hline Nuclear & 7.8 & 9.3 & 9.3 \\
\hline Eolic & 9.3 & 20.7 & 27.3 \\
\hline Diesel (Fuel oil) & 14.0 & & \\
\hline
\end{tabular}

Source: Yepez-Garcia, R.A.; Johnson, T. M.; Andres, L.A. (2010). Meeting the Electricity Supply/Demand

Balance in Latin America \& at the Caribbean, ESMAP, Energy Unit LCSSD.

It is important to note that these calculations were made under specific assumptions of fuel costs, load factors (electrical), interest rates, and plant useful lives. Therefore, it is likely that the figures do not reflect country-specific characteristics; however, they allow us to have a rough idea of these costs as part of the cost of generation. 
Considering the macroeconomic trends, supply and demand of electricity and other factors, Yepez-Garcia, et al (2010) estimate that coal plants and natural gas will remain with a significant percentage of the energy mix by 2030 as shown Table 3.

Yepez-Garcia, et al (2010) also estimated that from the total new installed capacity for electricity generation in Mexico that will be increased in 2030,51\% will correspond to natural gas, $23 \%$ to coal-fired plants and $14 \%$ to hydroelectric projects. This reveals that both Mexico and Latin America and the Caribbean, despite efforts to control GHG emissions from its electricity industry, show scenarios where $\mathrm{CO}_{2}$ emissions will continue to grow, in a slower rate, but will continue to grow. If Mexico's electricity industry generated more than 100,000 kilo-tons of $\mathrm{CO}_{2}$ in 2008, it is estimated that this figure will reach around 200,000 kilo-tons in 2030 according to the projections.

Table 3. Projected energy mix in power generation by 2030: Latin America and the Caribbean vs. Mexico

\begin{tabular}{|c|c|c|c|c|}
\hline \multirow[t]{2}{*}{ Types of Technology } & $\begin{array}{c}\text { Latin America and } \\
\text { the Caribbean } \\
\mathbf{2 0 0 8} \\
\end{array}$ & $\begin{array}{c}\text { Latin America and } \\
\text { the Caribbean } \\
2030 \\
\end{array}$ & $\begin{array}{c}\text { Mexico } \\
2008\end{array}$ & $\begin{array}{c}\text { Mexico } \\
2030\end{array}$ \\
\hline & Mix (\%) & Mix (\%) & Mix (\%) & Mix (\%) \\
\hline Biomass & $0.50 \%$ & $2.00 \%$ & $0.00 \%$ & $0.00 \%$ \\
\hline Coal & $4.60 \%$ & $7.90 \%$ & $12.00 \%$ & $15.00 \%$ \\
\hline Diesel & $2.30 \%$ & $1.20 \%$ & $0.00 \%$ & $1.00 \%$ \\
\hline Eolic & $0.10 \%$ & $1.30 \%$ & $0.00 \%$ & $1.00 \%$ \\
\hline Fuel Oil & $8.40 \%$ & $3.30 \%$ & $18.00 \%$ & $3.00 \%$ \\
\hline Gas & $22.00 \%$ & $29.40 \%$ & $50.00 \%$ & $65.00 \%$ \\
\hline Geothemal & $1.00 \%$ & $0.80 \%$ & $3.00 \%$ & $2.00 \%$ \\
\hline Hydroelectric & $50.60 \%$ & $50.00 \%$ & $12.00 \%$ & 10.00 \\
\hline Nuclear & $2.80 \%$ & $4.20 \%$ & $4.00 \%$ & $3.00 \%$ \\
\hline
\end{tabular}

Source: Yepez-Garcia, et al.(2010)

\section{CONCLUSION}

Although the use of coal pollutes the environment, it will continue to be used as fuel for coal-fired power plants in some countries where coal exists in abundance. There will also be technological developments that will seek proper ways of mitigating their emissions to minimize the impact that these plants might have on the environment.

Are there going to be technological breakthroughs in other types of power generation (renewable energies), or new market conditions that could impact the investment decisions about the type of power plants that could generate a new trend in the generation of electricity? The answer is still unknown.

From a technical, economic and financial point of view, coal-fired power plants will continue to be a reliable and profitable source of electrical power for many countries. If they are implemented under optimal conditions, they can still be a very good option for electricity generation. It might be possible that coal could emerge as a cheap, safe, and efficient fuel to generate electricity, especially in those countries whose economies live from the exploitation and use of coal such as the U.S.A (Kentucky), China, Colombia, and Mexico. The challenge is to make coal to become a fuel aligned to sustainable production in the future; this will be important to the more than 1,300 coal-fired power plants existing in the world. In the electricity generation industry not everything is said yet, its transformation will continue to surprise the world.

\section{AUTHOR INFORMATION}

Flory Anette Dieck-Assad, Ph.D. in Finance from Tulane University (2003). Author of the textbook "Financial Institutions" by McGraw-Hill used by all the universities of the country. Invited lecturer in Mexico, Chile, U.S.A., Canada, and Europe, got the "Best Lecture Award" in 2004, 2008, 2010, 2011, 2012, 2013, 2014 and 2015. She has more than 170 publications in national/international magazines, reviews, and journals. She got the "Prize to Education and Research 2007, 2010, and 2014". Texas A\&M University Press published her book: "Energy and Sustainable Development in Mexico" (2008), honored with the "National Romulo Garza Award for the Best Written Book". Tenured Professor at Tecnologico de Monterrey. Received the 2013 National Ethics Award in Academic Teaching, 
2015 Professor of the Year, 2015 Distinguished Professor of the Institute of Chartered Accountants of the State of Nuevo Leon, Mexico, and the 2015 National Energy Prize for her contributions to the energy sector. Member of the Mexican National System of Researchers (SNI).

\section{REFERENCES}

Boulanger, S.; Barnes, D.; Araya, M. K. (2009). ESMAP CY2007-FY2008 annual report. Energy Sector Management Assistance Program. Washington, DC: World Bank. http://documents.worldbank.org/ curated/en/2009/01/10607349/esmapcy2007-fy2008-annual-report

Bruggers, J. (2011). University of Kentucky gets \$19.4 million for coal research, Energize Weekly, 4(33), August 17.

Cengel, Y. \& Boles, M. (2012). Termodinámica. México, McGraw-Hill.

CO2 Solutions Inc. (2015). CO2 Solutions Accelerates Pursuit of Commercial Opportunities by Bringing Forward Demonstration Project, PRNewswire, a UBM plc company, http://www.prnewswire.com/news-releases/co2-solutionsaccelerates-pursuit-of-commercial-opportunities-by-bringing-forward-demonstration-project-502732191.html

Girardin L. O. (2011). El mecanismo para un desarrollo limpio en América Latina. Voces en el Fénix, Noviembre, 10, 86-91.

Greenpeace (2002). Petacalco: la central carbonífera. www.greenpeace.org/mexico/Global/.../petatalco.pdf

Kolomitz, C. (2012). Southern Co teams with KBR for high tech coal power, Energize Weekly, 5(44), October 31.

Martínez-Prado, M.A.; Unzueta-Medina, J.; Pérez-López, M.E (2014). Electrobioremediation as Hybrid Technology to treat soil contaminated with total petroleum hydrocarbons, Revista Mexicana de Ingeniería Química, 13(1) 113-127, Universidad Autónoma Metropolitana Unidad Iztapalapa, D.F. México.

Ortuño, A. (1998). Introducción a la química industrial. España.

Rincon, J. M. (2002). El carbon y su problematica ambiental. Revista de la Academia Colombiana de Ciencias, 26(6), $271-277$.

Southern Company (2015). Kemper County Energy Facililty, http://www.southerncompany.com/what-doing/energyinnovation/smart-energy/smart-power/kemper.cshtml?gclid=CK7nvPb_1cUCFQioaQodcCYAeA

The World Bank Group (2007). ESMAP (Energy Sector Management Assistance- Program), Technical Paper 121/07, December, Washington, D.C.

Yepez-Garcia, R.A.; Johnson, T. M.; Andres, L.A. (2010). Meeting the Electricity Supply/Demand Balance in Latin America \& athe Caribbean, ESMAP, Energy Unit LCSSD. 
NOTES 